\title{
CT ring sign imitating tumour, disclosed as multiple sclerosis by MRI: a case report
}

\author{
EVA GÜTLING, THEODOR LANDIS \\ From the Department of Neurology, University Hospital, Zürich, Switzerland
}

SUMMARY A 21 year old woman with subacute onset of moderate left hemiparesis showed on CT scanning a left parietal ring shaped enhancing lesion indicative of tumour or abscess, while MRI revealed bilateral white matter lesions highly suggestive of MS. In none of the few similar cases reported was MRI available and most patients underwent biopsy or operation. The few reports of a CT-ring sign in MS are reviewed and the value of MRI in avoiding operation is stressed.

Cranial computed tomography (CT) abnormalities are found in about $30 \%$ of patients with multiple sclerosis.' The most common presentations are focal areas of reduced attenuation in the white matter ${ }^{2}$ but in patients with an acute exacerbation a CT scan after contrast-enhancement may show white matter foci of increased density. ${ }^{3}$ Contrast enhancement is believed to represent a local break-down of the blood-brain barrier accompanying active demyelination. ${ }^{45}$ On the other hand MRI is well-known to detect demyelinating lesions reliably even when CT scanning fails to demonstrate them.

Ring shaped enhancing CT lesions are commonly seen in brain metastases, brain abscesses or in primary brain tumours. In multiple sclerosis this enhancing CT ring sign is exceedingly rare. It has been associated with an unusually malignant course and in most of the few reported cases ${ }^{16-12}$ MRI was unavailable, and the diagnosis was made by brain biopsy or even open surgery. We report a case in which the divergence between the clinical symptoms and the site of a CT ring sign led to MRI and this avoided other, potentially dangerous diagnostic procedures.

\section{Case report}

In September 1987 a 21 year old right handed woman was admitted to our hospital with a 3 day history of weakness and transitory dysaesthesias in the left arm and leg. Her previous medical history was unremarkable except for alcohol abuse

Address for reprint requests: Dr Eva Gütling, Neurologische Klinik, Universitätsspital, CH-8091 Zürich, Switzerland.

Received 22 July 1988 and in revised form 18 February 1989. Accepted 28 February 1989 for three years. Examination showed a moderate left hemiparesis with increased tendon reflexes on the left side and a mild left sided pallhypaesthesia. Both plantars were flexor. There were no other sensory or motor abnormalities and the cranial nerves and coordination were intact. Mental status examination showed mild visuo-spatial difficulties and an impaired recall of learned verbal information. CT scan with contrast enhancement ( $36 \mathrm{~g} \mathrm{I}_{2}$, single dose, immediate scanning) showed a large left parietal ring-shaped enhancing white matter lesion, (fig, top left). MRI later same day demonstrated multiple bilateral white matter lesions, the largest corresponding to the CT ring sign (fig, top right).

Serological examination for HIV, toxoplasmosis, Lyme disease, syphilis, and a variety of neurotropic viruses were negative. CSF examination showed a mild mononuclear pleocytosis of 7 cells $/ \mathrm{mm}^{3}$ while the total protein content was within normal limits. There was an increase of $\operatorname{IgG}(0 \cdot 167 \mathrm{~g} / \mathrm{l}$; norms $0.08-0 \cdot 12 \mathrm{~g} / \mathrm{l})$ and oligoclonal bands were present. Visual evoked potentials and somatosensory evoked potentials were within normal limits. On the basis of the clinical picture and the MRI and CSF findings the diagnosis of "laboratory supported probable MS (LSPMS)"13 was made. She was given a course of prednisone $100 \mathrm{mg}$ once a day for 10 days during which her left hemiparesis gradually improved and the dysaesthesias disappeared. Six weeks after the onset of the symptoms, the CT scan and MRI were repeated (fig, bottom).

On the CT scan the left parietal low density area remained but the ring sign had completely disappeared. On MRI the lesion was unchanged, other bilateral white matter lesions were still present and additional small periventricular lesions could be seen. Close clinical observation for over nine months has not revealed any new clinical signs and symptoms but a very mild left hemiparesis persists.

\section{Discussion}

Contrast enhancement in cerebral lesions on com- 

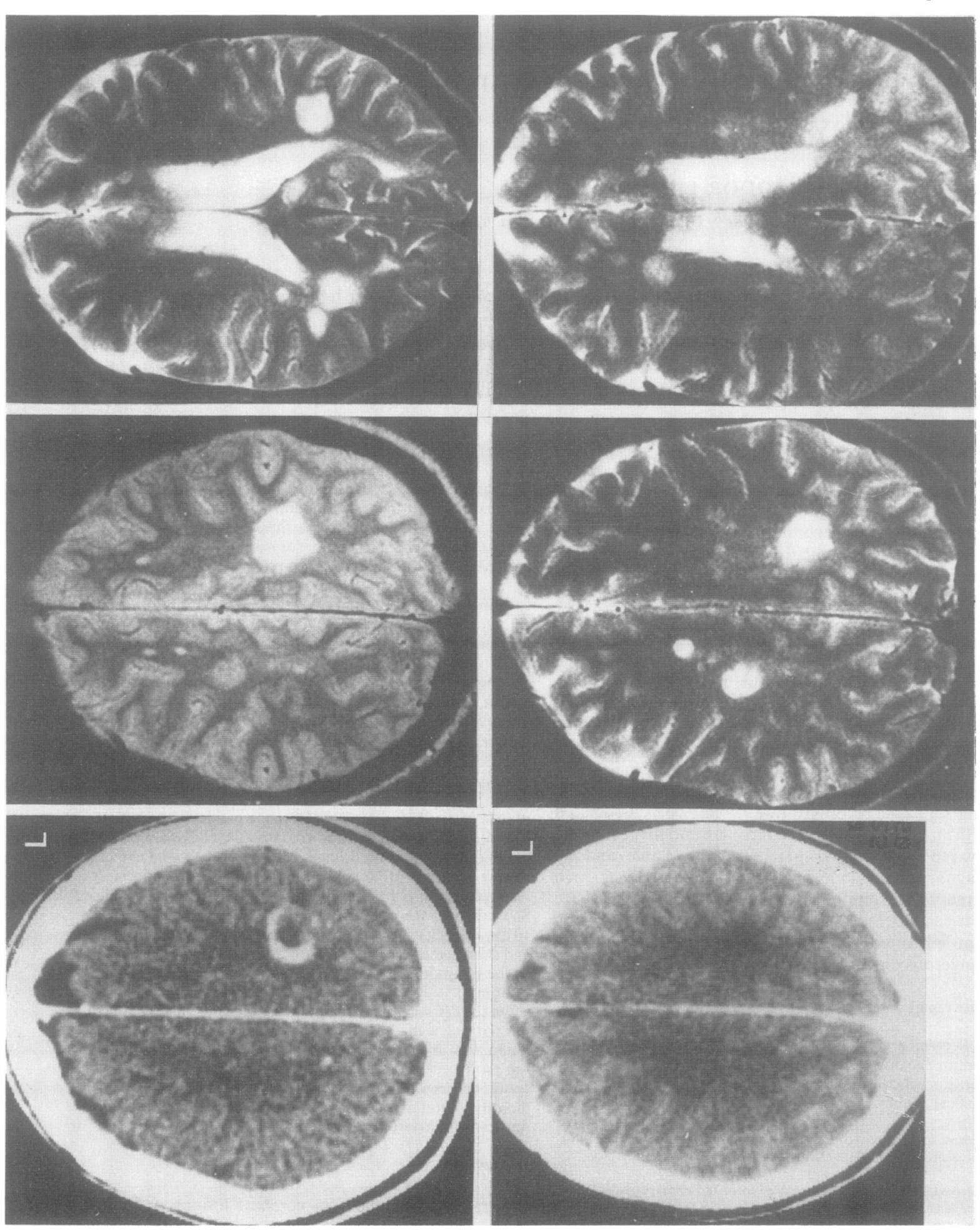
Table Clinical summary of the ten reported cases of CT ring sign in multiple sclerosis

\begin{tabular}{|c|c|c|c|c|c|c|c|c|c|c|}
\hline & $\begin{array}{l}\text { Age } \\
(y r)\end{array}$ & Sex & $\begin{array}{l}\text { lst Mani- } \\
\text { festation }\end{array}$ & Symptoms & Follow-up & Severity & Death & $\begin{array}{l}\text { Biopsy/ } \\
\text { Operation }\end{array}$ & $\begin{array}{l}\text { Steroid- } \\
\text { therapy }\end{array}$ & $C T$ repeated \\
\hline Nelson $^{6}$ & 38 & $\mathbf{F}$ & - & $\begin{array}{l}\text { Hemiparesis } \\
\text { Confusion } \\
\text { Dysarthria }\end{array}$ & 1 month & + & - & + & - & $\begin{array}{l}\text { slight decrease of } \\
\text { enhancement after } \\
3 \text { weeks }\end{array}$ \\
\hline $\begin{array}{l}\text { Van der } \\
\text { Velden? }\end{array}$ & 60 & $\mathbf{M}$ & - & $\begin{array}{l}\text { Aphasia } \\
\text { Tetraparesis } \\
\text { Ataxy }\end{array}$ & 6 months & + & + & + & + & $\begin{array}{l}\text { after } 4 \text { months the } \\
\text { lesion disappeared, new } \\
\text { lesion appeared }\end{array}$ \\
\hline \multirow[t]{3}{*}{ Sagar ${ }^{8}$} & 34 & $\mathrm{~F}$ & - & $\begin{array}{l}\text { Status epilepticus } \\
\text { Aphasia } \\
\text { Confusion }\end{array}$ & 15 months & + & + & - & - & $\begin{array}{l}\text { residual low density } \\
\text { after } 7 \text { months }\end{array}$ \\
\hline & 37 & $\mathbf{M}$ & - & $\begin{array}{l}\text { GM-seizures } \\
\text { Aphasia }\end{array}$ & 6 months & + & - & + & - & \multirow{7}{*}{$\begin{array}{l}\text { residual low density } \\
\text { no enhancement } \\
1 \text { month later } \\
\text { residual low density } \\
\text { no enhancement } \\
1 \text { month later } \\
\text { residual low density } \\
\text { no enhancement } \\
4 \text { months later } \\
\text { (multiple ring les.) } \\
\text { ring enhancement only } \\
6 \text { weeks after onset of } \\
\text { symptoms, no } \\
\text { follow-up } \\
\text { residual low density } \\
4 \text { weeks later, near } \\
\text { resolution } 1 \text { year later } \\
\text { decrease of low dens }\end{array}$} \\
\hline & 24 & $\mathbf{M}$ & + & $\begin{array}{l}\text { Headache } \\
\text { GM-seizures }\end{array}$ & 6 months & + & - & + & + & \\
\hline Vliegenhart ${ }^{9}$ & 28 & $\mathbf{F}$ & + & $\begin{array}{l}\text { Confusion } \\
\text { Somnolence } \\
\text { slurred speech }\end{array}$ & 5 months & + & - & - & + & \\
\hline Wang' & 39 & $\mathbf{F}$ & + & $\begin{array}{l}\text { Dysarthria } \\
\text { facial weakness } \\
\text { sensibility disorder }\end{array}$ & 2 months & + & - & + & - & \\
\hline Moreno $^{10}$ & 32 & $\mathbf{M}$ & + & $\begin{array}{l}\text { leg weakness and } \\
\text { numbness }\end{array}$ & 12 months & - & - & - & - & \\
\hline Morimoto" & 9 & $\mathbf{M}$ & - & $\begin{array}{l}\text { Headache, Hemi- } \\
\text { paresis, Aphasia }\end{array}$ & 1 month & + & - & - & + & \\
\hline Bittencourt $^{12}$ & 48 & $\mathbf{M}$ & - & $\begin{array}{l}\text { Confusion } \\
\text { Hemiparesis }\end{array}$ & 2 months & + & + & + & + & \\
\hline
\end{tabular}

puted tomography is generally believed to represent a local breakdown of the blood brain barrier. When the enhancement occurs in a ring-like fashion the phenomenon has been referred to as the CT ring sign. This CT ring sign is commonly observed with primary and secondary malignant brain tumours and with brain abscesses. In multiple sclerosis the $\mathrm{CT}$ ring sign is very rare and may be difficult to differentiate from these other conditions, especially when there is a mass effect.

Table 1 summarises the clinical picture of the 10 reported cases of CT ring sign in MS. In contrast to the present patient, nine of the ten cases showed a particularly severe clinical course with headache, aphasia, seizures, and confusion. Three of these patients died within 15 months. Such a severe clinical course is unusual in multiple sclerosis and far more suggestive of brain tumour or abscess; this led to biopsy and even operation in six of these patients. The differential diagnosis may become especially difficult if the CT ring sign appears at the first manifestation of the disease as was the case in our patient and in four of the previously-reported cases. Initially the lack of mass effect has been thought to differentiate the multiple sclerosis plaque from space occupying lesions, ${ }^{3}$ but recent reports ${ }^{16-12}$ have shown this to be incorrect. Follow-up CT scans after two to four weeks have been suggested to be useful in confirming the diagnosis of multiple sclerosis. ${ }^{167}$ However, the suspicion of a potentially life threatening space occupying lesion such as a brain tumour or abscess may preclude such an expectant attitude.

The advent and increasing availability of MRI has much simplified the differential diagnosis of multiple sclerosis; for the first time demyelinating lesions can be reliably visualised. Moreover, contrast enhancement of multiple sclerosis plaques has been seen with the paramagnetic agent gadolinium DTPA and appears to be more frequent in new lesions. ${ }^{14}$ In contrast to the rarity of the ring sign in CT, gadolinium DTPA ring enhancement of multiple sclerosis lesions is more common in MRI and is thought to represent active demyelination at the edge of the plaque. ${ }^{15}$ However, when the lesion is a tumour, MRI frequently provides little more information than CT scan because it may be difficult to differentiate tumour from surrounding oedema. For this reason, if the side of the CT ring sign had not been incompatible with the clinical deficit, the subacute onset of a progressive hemiparesis in conjunction with a CT ring sign would probably have led us to consider operating upon our patient without additional MRI. In the light of this case and those previously reported, we recommend additional MRI, if available, in every patient presenting with a ring shaped enhancing lesion in order to avoid a surgical 
diagnosis of multiple sclerosis.

We thank Drs Jane Casey and Marianne Regard for their helpful advice.

The study was presented in part at the 1st European Congress of Neurology, Prague/Czechoslovakia, April, 1988.

\section{References}

1 Wang AM, Morris JH, Hickley WF, Hammerschlag SB, O'Reilly GV, Rumbaugh CL. Unusual CT patterns of multiple sclerosis. Am J Neuroradiology 1983;4:47-50.

2 Wüthrich R, Gigli H, Wiggli U, Müller HR, Elke M, Hunig R. CT scanning in demyelinating disease. In: Lanksch W, Kazner E, eds. Cranial Computerized Tomography: Berlin: Springer, 1976:239-43.

3 Harding AE, Radue EW, Whiteley AM. Contrastenhanced lesions on computerised tomography in multiple sclerosis. J Neurol Neurosurg Psychiatry 1978; 41:754-8.

4 Gado MH, Phelps ME, Coleman RE. An extravascular component of contrast enhancement in cranial computed tomography: I. The tissue-blood ratio of contrast enhancement. Radiology 1975;117:589-93.

5 Gado MH, Phelps ME, Coleman RE. An extravascular component of contrast enhancement in cranial computed tomography: II. Contrast enhancement and the blood-tissue barrier. Radiology 1975;117:595-7.

6 Nelson MJ, Miller SL, McLain W, Gold LHA. Multiple
Sclerosis: Large plaque causing mass effect end ring sign. J Comp Ass Tomography 1981;5:892-4.

7 Van der Velden M, Bots GTA, Endtz LJ. Cranial CT in multiple sclerosis showing a mass effect. Surg Neurol 1979;12:307-10.

8 Sagar HJ, Warlow CP, Sheldon PWE, Esiri MM. Multiple sclerosis with clinical and radiological features of cerebral tumour. J Neurol Neurosurg Psychiatry 1982;45:802-8.

9 Vliegenthart WE, Sanders EACM, Bruyn GW, Vielvoye GJ. An unusual CT-scan appearance in multiple sclerosis. J Neurol Sci 1985;71:129-34.

10 Moreno AL, Brown JM, Waller SF, Lundy MM, Brown TJ. The complementary roles of brain scintigraphy and computed tomography in multiple sclerosis. Clin Nucl Med 1983;8:618-22.

11 Morimoto T, Nagao H, Sano N, Habara S, et al. A case of multiple sclerosis with multi-ring-like and butterfly-like enhancement on computerized tomography. Brain Dev 1985;7:43-5.

12 Bittencourt PRM, Kendall BE. Computerized axial tomography and diagnosis of multiple sclerosis. Arg Neuro-Psiquiatria 1983;41:171-81.

13 Poser CM, Paty DW, Scheinberg L, et al. New diagnostic criteria for multiple sclerosis: Guidelines for research protocols. Ann Neurol 1983;13:227-31.

14 Grossman RI, Gonzalez-Scarano F, Atlas SW, Galetta S, Silberberg DH. Multiple sclerosis: gadolinium enhancement in MR imaging. Radiology 1986;161:721-5.

15 Miller DH, Rudge P, Johnson G, et al. Serial gadolinium enhanced magnetic resonance imaging in multiple sclerosis. Brain 1988;111:927-39. 